\title{
PEROXISOME PROLIFERATOR-ACTIVATED RECEPTOR-GAMMA, AN EMERGING POTENTIAL TARGET TO COMBAT METABOLIC DISORDER
}

\author{
PARTHA SARATHI BAIRY* \\ Department of Pharmaceutical Sciences, Sardar Bhagwan Singh Post Graduate Institute of Biomedical Science and Research, Balawala, \\ Dehradun, Uttarakhand 248161, India. Email- bairy.partha@gmail.com
}

Received: 15 July 2017, Revised and Accepted: 15 September 2017

\begin{abstract}
Day-by-day metabolic disorder/syndrome (MS) falling in love with current lifestyle status of everyone especially after study age group of people. If we look carefully around us, we will see evidence is growing up of diabetic, obese, and hypertensive population regularly. In urgencies of above view extensive literature survey has been done prioritizing prevalence of metabolic disorder and peroxisome proliferator-activated receptor-gamma (PPAR- $\gamma$ ) as potential target protein. This review covered current status of MS emphasizing diabetes along with its management criteria. Special importance is given to PPAR- $\gamma$ exploring its metabolic regulation and structural orientation for understanding ligand-protein interaction. Development of PPAR- $\gamma$ agonist thiazolidinediones (TZDs) and other pharmacodynamic importance of this nuclear receptor also discussed. Being as nuclear receptor more genomics exploitation needs to be done emphasizing minimization of cardiac adverse effect. Selective PPAR modulator (SPPRM), TZDs are the master regulator of adipogenesis and angiogenesis which makes TZD more interesting topic to explore. Developmental hierarchy suggests that in a few years from now PPAR- $\gamma$ won't be in the list of double edge sword.
\end{abstract}

Keywords: Metabolic disorder, Diabetes, Peroxisome proliferator-activated receptor- $\gamma$, Retinoid X receptor, Thiazolidinedione, Dyslipidemia.

(C) 2017 The Authors. Published by Innovare Academic Sciences Pvt Ltd. This is an open access article under the CC BY license (http://creativecommons. org/licenses/by/4. 0/) DOI: http://dx.doi.org/10.22159/ajpcr.2017.v10i12.21569

\section{PREVALENCE OF METABOLIC DISORDER}

The modern lifestyle of $21^{\text {st }}$ century uplifts the priority of metabolic disorder in front of us where there is a high imbalance between intake and utilization of calorie. Concentrating on this increasing prevalence, multidisciplinary studies aimed at preventing and controlling metabolic disorder is a worldwide research priority. Metabolic disorder refers to a collection of various interrelated cardiometabolic risk factors that leads to the generation and development of cardiovascular dysfunction that contributes a major percentage in cardiovascular morbidity and mortality. The prevalence and incidence of certain disorders such as diabetes, dyslipidemias, obesity, hypertension, and atherosclerosis have been well defined in large population globally whether in the USA or in Southern Asia especially in India [1-3]. Data revealed that the percentage of metabolic syndrome (more than 33\%) in the USA increasing year by year and affected females more than males on any tested age group [4]. On an average, more than $30 \%$ of the Southern Asian population is in grasp of the same whether they are in the higher economic part of society or from lower socioeconomic background [5]. Metabolic disorder burden in urban areas of India estimated as ranges between 25 and 45\% [6]. Among all the diabetes mellitus is of main concern which contributed either by insulin resistance or by absolute deficiency in insulin secretion [7]. According to the recent estimate of American Diabetes Association, there were 30.3 million diabetics in 2015 in USA and prediabetics were estimated as 84.1 million which was 79 million in 2010 [8]. According to the World Health Organization estimation worldwide 422 million (8.5\% of total population) people had diabetes. The global burden of diabetes has been increasing by large stair step since past 3 decades and is affecting rapidly in low- and middle-income countries [9-11].

\section{MANAGEMENT OF METABOLIC DISORDER}

The term "control" suits well than "prevention" when it comes for metabolic disorder management as being metabolism is a continuous process, and it alters the calorie level in physiological system every second. The control measures for the same is always dependent on caloric input-output ratio which directly or indirectly emphasize the risk factors of atherosclerotic cardiovascular diseases [7,12,13]. The stock two approaches managing this condition with great success include proper energy management by diet along with physical exercise habits first and pharmacological interventions secondly [12-15]. Either of those two or combination of them should lower the criteria for metabolic syndrome defined by National Cholesterol Education Program Adult Treatment Panel [16]. A new treatment strategy using designing prebiotics and probiotics with natural food products also trying to find a way to control this metabolic disorder [17]. Sometimes lifestyle changes are not enough to control the risk factors of metabolic syndrome, so doctors generally prescribed pharmacological agents to combat the situation which actually contributes the metabolic syndrome such as diabetes, dyslipidemia, atherosclerosis, and highpertension. In major cases, the treatment proceeds emphasizing diabetes and to the lower lipid levels. A diverse number of protein identified for managing diabetes such as $\alpha$-glucosidase, peroxisome proliferator-activated receptor-gamma (PPAR- $\gamma$ ) [18,19], sodium glucose cotransporter-2, dipeptidyl peptidase-IV, glucokinase, glucagon-like peptide-I [7,20,21], adenosine monophosphate activated protein kinase [22], and G proteincoupled receptor-119 (GPR-119) [23] and so on but PPARs snatching its importance as being a target protein for hyperlipidemia also.

\section{PPARS, TARGET FOR METABOLIC DISORDER}

The peroxisome proliferator-activated receptor first described 60 years back but discovered in the 1990s and named so as the ligands attached to this protein can control the proliferation of peroxisome in various tissue cells [24]. PPAR regulates biological processes influencing gene expression including glucose and lipid metabolism, cell proliferation, and inflammation regulation by activating transcription factor of targeting cells $[25,26]$. This receptor works better as agonist rather than antagonist and also classified as a full agonist, partial, dual agonist, and pan-agonist with other serotypes depending on binding and activity $[27,28]$. Till date, three PPAR subtypes encoded by separate genes have been discovered such as PPAR- $\alpha, \operatorname{PPAR}-\beta / \delta$, and PPAR- $\gamma$ [12]. These three isotypes of PPAR [29] distributed in different tissues and effective on selective genes and perform different biological functions (Table 1) [30-35]. 
Table 1: Comparisons of different PPAR subtypes

\begin{tabular}{|c|c|c|c|c|c|}
\hline S. No. & $\begin{array}{l}\text { PPAR } \\
\text { subtypes }\end{array}$ & $\begin{array}{l}\text { Tissue distribution } \\
\text { pattern }\end{array}$ & Target genes for enzymes & Biological function & Discovered clinical agents \\
\hline 1. & PPAR- $\alpha$ & $\begin{array}{l}\text { Liver } \\
\text { Heart } \\
\text { Muscles } \\
\text { Kidney }\end{array}$ & $\begin{array}{l}\text { Carnitine palmitoyltransferase I } \\
\text { HMG CoA synthase II } \\
\text { Apolipoprotein A-I }\end{array}$ & $\begin{array}{l}\text { Control genes involved in } \\
\text { the metabolism of lipids, } \\
\text { lipoproteins } \\
\text { Regulation fatty acid } \beta \text { oxidation }\end{array}$ & $\begin{array}{l}\text { Fibrates (e.g., clofibrate, } \\
\text { bezafibrate, fenofibrate) }\end{array}$ \\
\hline 2. & $\begin{array}{l}\text { PPAR- } \beta / \delta \\
\text { or PPAR- } \delta\end{array}$ & $\begin{array}{l}\text { Adipose tissue } \\
\text { Skin } \\
\text { Brain }\end{array}$ & $\begin{array}{l}\text { Acyl-CoA oxidase } \\
\text { Carnitine palmitoyltransferase I }\end{array}$ & $\begin{array}{l}\text { Lipid metabolism } \\
\text { Energy balance in various large } \\
\text { tissues }\end{array}$ & $\begin{array}{l}\text { GW501516 } \\
\text { GW0742 (both are in } \\
\text { clinical trial phase) }\end{array}$ \\
\hline 3. & PPAR- $\gamma$ & $\begin{array}{l}\text { Adipose tissue } \\
\text { Macrophage }\end{array}$ & Lipoprotein lipase & $\begin{array}{l}\text { Differentiates adipocytes } \\
\text { Fatty acid trapping }\end{array}$ & $\begin{array}{l}\text { Thiazolidinediones (e.g., } \\
\text { Rosiglitazone, pioglitazone) }\end{array}$ \\
\hline
\end{tabular}

HMG CoA-3-Hydroxy 3-Methyl Glutaryl Coenzyme A. PPAR: Peroxisome proliferator-activated receptor

\section{PPAR- $\gamma$ AND METABOLIC REGULATION}

The PPAR- $\gamma$ is a nuclear receptor that regulates glucose metabolism with two effectors binding site called activation function 1 (AF1) and AF2. The receptor's central deoxyribonucleic acid (DNA) binding domain is followed by the C-terminal ligand binding domain (LBD), which comprises AF2. PPAR- $\gamma$ is regulated by a phosphorylation site in the LBD at Ser-273 (Ser-245 in the shorter isoform 1) [12]. In recent years, PPAR- $\gamma$ emerged as an attractive target for drug development, mainly control the expression of gene networks involved in metabolic homeostasis, adipogenesis, lipid metabolism, carcinogenesis and inflammation. Fatty acids and eicosanoids are the endogenous ligands of PPAR- $\gamma$, can be activated by dietary fats and their metabolites, act as lipid sensors that, on activation, are able to markedly redirect metabolism by ligand-activated transcription factors that bind to moreor-less specific sequences of the genome and thereby control gene expression [36]. In the absence of ligands, PPAR- $\gamma$ form heterodimer with retinoid $X$ receptor (RXR), another nuclear receptor, and helps in transcription of target genes by binding to PPAR response elements in the promoter region of target genes [37]. Ligands bind at the PPAR, particularly at LBD brings the changes in target genome which express the final changes in the transcription process. The newly synthesized messenger ribonucleic acid (mRNA) travelled to the cytoplasm through nuclear pores and express in protein at ribosome to alter several PPAR responsible biological events (Fig. 1).

\section{PPAR- $\boldsymbol{\gamma}$ - Structural insight}

First three-dimensional X-ray crystallographic structure of PPAR- $\gamma$ studied in 1998 and since then lots of ligand-based cocrystal structure reported in protein data bank [38]. The structure of PPAR- $\gamma$ composed of two prime regions, i.e., DNA binding domain (DBD) and LBD. The DBD region of PPAR- $\gamma$ commonly attached to the peroxisome proliferator response elements (PPRE) of DNA sequence in the 5 ' end. Here carboxyterminal extension of PPAR- $\gamma$ causes a significant DNA interaction. LBD is separated from DBD by two helical segments. RXR heterodimerize with PPAR- $\gamma$ as a fashion that the LBD of PPAR- $\gamma$ is closely packed between DBD and LBD of RXR to keep them separated from each other (Fig. 2) [39]. Ligands of PPAR- $\gamma$ induce a "Y" shaped binding pocket where there remains a covalent bond between ligands and amino acid Cysteine [40]. Most of the ligands interact with PPAR- $\gamma$ composed of polar head and hydrophobic tail allowing hydrophobic interaction at the binding region. Ser-289, His-323, His-449, and Tyr-473 (Fig. 3) contributes the important amino acid residues around binding pocket that allow hydrogen bonding with carboxylic acids of natural modulators or keto group of synthetic agonist thiazolidinediones (TZDs) [41-43].

\section{Historical chronology of PPAR- $\gamma$ ligands}

The first glitazone was introduced by 1990s and since then PPAR- $\gamma$ agonist has emerged as very crucial class of agents to combat insulin resistance in humans either with diet or with other class of oral hypoglycemics. It was 1995 when TZD moiety proved to have insulin sensitivity and first agent troglitazone (TRO) approved by United State Food and Drug Administration in 1997 came to consideration [30,44]. Although TRO was withdrawn from the market due to safety issues, it

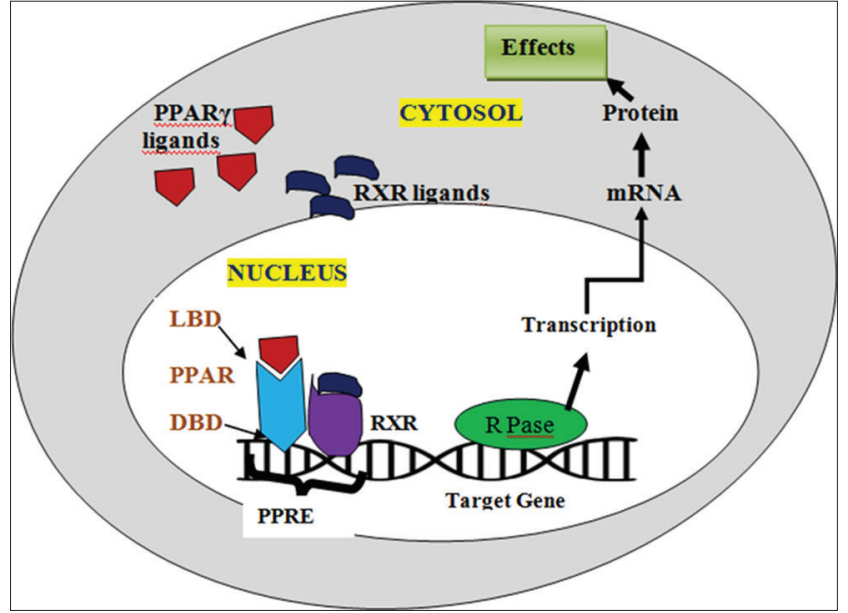

Fig. 1: Metabolic regulation of PPAR $\gamma$ as a nuclear receptor. PPAR: Peroxisome proliferated-activated receptor, RXR: Retinoid X receptor, LBD: Ligand binding domain, DBD: DNA binding domain, PPRE: Peroxisome proliferated response elements, R Pase: RNA polymerase, and mRNA: messenger ribonucleic acid

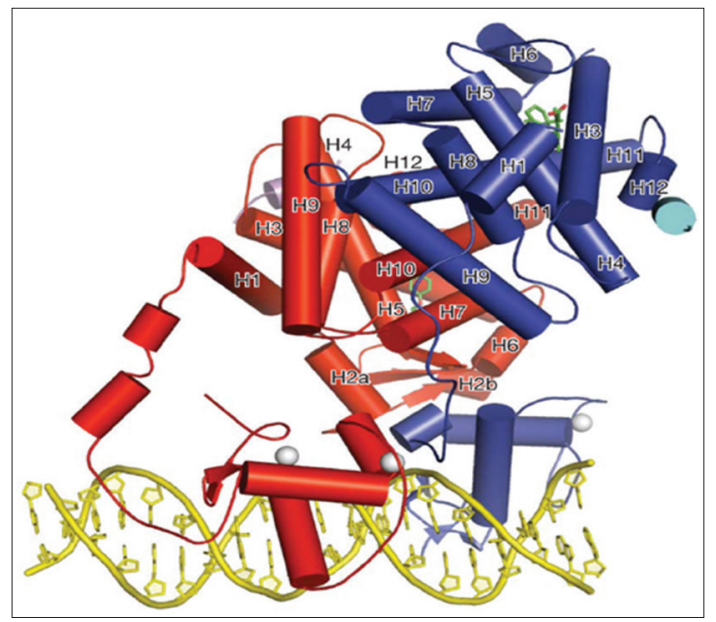

Fig. 2: X-Ray crystal structure of peroxisome proliferatoractivated receptor-gamma (PPAR- $\gamma$ ) heterodimer with retinoid $X$ receptor (RXR). PPAR- $\gamma$ in red color and RXR in blue

was potential lead to enlighten the discovery of other TZDs as PPAR- $\gamma$ agonist. Drug-induced liver failure was the main concern about prototype TRO being removed from the market in 2000. Pioglitazone and Rosiglitazone are the two agents approved in 1999 and still available in the market as insulin sensitizer of TZD [45]. Despite some adverse 


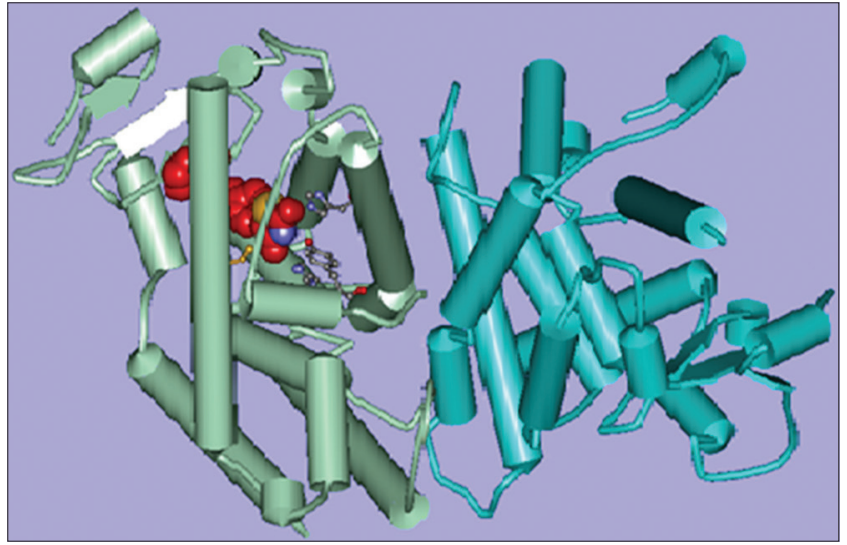

Fig. 3: Structure of peroxisome proliferator-activated receptorgamma with rosiglitazone (PDB ID - 4EMA). Ligand binding domain (LBD) in grayish green, DNA binding domain in blue, Rosiglitazone in red, and ball and stick represents the amino acid residues in the binding pocket of LBD

Table 2: Natural and synthetic agonist of PPAR- $\gamma$

\begin{tabular}{ll}
\hline Natural agonist & Synthetic agonist \\
\hline $\begin{array}{l}\text { Amorfrutins (Amorfrutin 1, } \\
\text { Amorfrutin 2, Amorfrutin B) }\end{array}$ & $\begin{array}{l}\text { TZDs (TRO, rosiglitazone, } \\
\text { pioglitazone, ciglitazone, } \\
\text { balaglitazone) }\end{array}$ \\
$\begin{array}{l}\text { Flavonoids (quercetin, catechin, } \\
\text { luteolin, etc.) }\end{array}$ & GW2570 - Clinical stage \\
$\begin{array}{l}\text { Stilbene (resveratrol) } \\
\text { Lignan (magnolol) } \\
\text { Chelerythrine }\end{array}$ & GW 1929 - Clinical stage \\
\hline
\end{tabular}

PPAR- $\gamma$ : Peroxisome proliferator-activated receptor-

gamma, TZDs: Thiazolidinediones, TRO: Troglitazone

effects, constant clinical investigation supported significant glycemic improvement potency of them. However, extensive monotherapy of this class is limited by fluid retention and other toxicities (cardiac, skeletal muscle, renal and bone marrow) [46-48]. Edema and weight gain contribute the major adverse effects of glitazones and established facts suggest that heart affects the most in human and other experimental animals. Although in terms of potential affinity, pioglitazone has less activity toward cardiac tissue than rosiglitazone.

\section{Drug development of PPAR- $\gamma$ ligands toward insulin resistance} Endogenous ligands for PPAR- $\gamma$ include free fatty acids, oxidized plasma lipoproteins, eicosanoids, some polyunsaturated fatty acids (mainly DHA and EPA) and platelet activating factors [49]. A wide number of natural as well as synthetic exogenous ligands (Table 2) were discovered and developing on clinical stages targeting PPAR- $\gamma$ to improve insulin resistance in human. TZDs are the synthetic ligands for agonism of nuclear receptor PPAR- $\gamma$. Starting with TRO to Balaglitazone [50,51] new glitazones are developing, but some are failing at various phases of clinical investigation as they associated with various toxicities. Non-TZD agonist (GW2570) [52] also developing still nuclear receptor targeted agents with strong efficacy and less toxicity is a major challenge to research community. To overcome this problem, new research proposals on pipeline to establish partial, dual PPAR (PPAR $\alpha / \gamma$ and PPAR $\delta / \gamma$ ) [53] and pan-PPAR [54] agonist which may reduce the toxicities by weak specificity toward PPAR- $\gamma$ without effecting efficacy. Here, the list of natural $[12,55,56]$ and synthetic $[44,45,52,57,58]$ modulators of PPAR- $\gamma$ given.

\section{PPAR- $\gamma$ and other pharmacodynamics}

The superfamily of nuclear receptor PPARs especially PPAR- $\gamma$ is associated with other pharmacological attributions. Along with combating diabetic condition, they have widely accepted potency for obesity as PPAR- $\gamma$ is highly expressed in adipose tissue. Among two different isoforms of PPAR $\gamma$ : PPAR- $\gamma 1$ and PPAR- $\gamma 2$, PPAR $\gamma 2$ is adipose tissue-specific. They have a lethal effect on adipocyte differentiation on the gene responsible for adipocyte lipid-binding protein (aP2), phosphoenolpyruvate carboxykinase, acyl-CoA synthase, and lipoprotein lipase as well as induce negative signal for other tissues to accumulate triglycerides (TG) [59]. Natural anti-inflammatory ligand 15d-PGJ2 [60] and nonsteroidal anti-inflammatory agents (NSAIDs) including ibuprofen, fenoprofen and indomethacin [61] have PPAR- $\gamma$ agonistic effect. These agents induce anti-inflammatory effect by targeting PPAR- $\gamma$ which inhibit production of inflammatory cytokines, such as tissue necrosis factor-alpha, interleukin-1 (IL-1) and IL-6, known as major contributors of inflammation $[59,61]$. PPAR- $\gamma$ is now a research hotcake for targeting angiogenesis and studies indicate that they not only target the gene responsible for cell division but also negatively regulate the cell cycle [62]. TZDs, the synthetic ligands of PPAR- $\gamma$ inhibits the proliferation of malignant cells or antiangiogenic for breast adenocarcinoma, prostate carcinoma, colorectal carcinoma, non-small cell lung carcinoma, pancreatic carcinoma, bladder cancer, gastric carcinoma and glial brain tumors [61-63]. They also have a weak binding potential toward those tissues where PPAR- $\alpha$ distributed and are used in treating hyperlipidemia in atherosclerosis, reduce triglyceride-rich very low-density lipoprotein synthesis in the liver. New research agenda trying to establish other pharmacological aspects such as autism [64], steatohepatitis [65] and ovarian hyperstimulation [66] of PPAR- $\gamma$ targeting agents.

\section{CONCLUSION}

Considering increasing prevalence of glucose intolerance and modern lifestyle issue metabolic disorder is a global burden. Besides altering day-to-day life energy consumption/ expenditure ratio pharmacon is also playing a major role to balance the abnormality of metabolism. Nuclear superfamily PPARs are of intense research interest being distributed to those tissues responsible for metabolic homeostasis. Along with other isoforms, PPAR- $\gamma$ managing the metabolic prevalence such as hyperglycemia, dyslipidemia and atherosclerosis with high hope. The main challenging fact of PPAR- $\gamma$ agonist TZDs is cardiovascular risk factors. There remains the prime interest to develop new PPAR- $\gamma$ agonist with promising clinical data. A huge number of enthusiastic works ongoing to develop partial as well as a dual agonist with less toxicity data and future looks in great urge to control the protein only for reducing metabolic worse conditions.

\section{REFERENCES}

1. Golden SH, Robinson KA, Saldanha I, Anton B, Ladenson PW. Clinical review: Prevalence and incidence of endocrine and metabolic disorders in the United States: A comprehensive review. J Clin Endocrinol Metab 2009;94(6): 1853-78.

2. Pradeepa R, Surendar J, Indulekha K, Chella S, Anjana RM, Mohan V. Prevalence of metabolic syndrome and its association with coronary artery disease among an Urban Elderly South Indian population (CURES- 145). J Assoc Physicians India 2016;64(5):20-5.

3. Prasad DS, Kabir Z, Dash AK, Das BC. Prevalence and risk factors for metabolic syndrome in Asian Indians: A community study from urban Eastern India. J Cardiovasc Dis Res 2012;3(3):204-11.

4. Aguilar M, Bhuket T, Torres S, Liu B, Wong RJ. Prevalence of the metabolic syndrome in the United States, 2003-2012. JAMA 2015;313(19):1973-4.

5. Misra A, Khurana L. The metabolic syndrome in South Asians: Epidemiology, determinants, and prevention. Metab Syndr Relat Disord 2009;7(6):497-514.

6. Ravikiran M, Bhansali A, Ravikumar P, Bhansali S, Dutta P, Thakur JS, et al. Prevalence and risk factors of metabolic syndrome among Asian Indians: A community survey. Diabetes Res Clin Pract 2010;89(2):181-8

7. Bairy PS, Shankar B, Das A. Diabetes mellitus and antidiabetics with reference to alpha glucosidase inhibitors. J Biomed Pharm Res 2015;4(6):10-6.

8. American Diabetes Association. Statistics about Diabetes. Available from: http://www.diabetes.org/diabetes-basics/statistics. [Last updated on June 17]. 
9. WHO. WHO Library Cataloguing-in-Publication Data, Global Report on Diabetes. Geneva: World Health Organization; 2016.

10. Roglic G. WHO Global report on diabetes: A summary. Int $\mathrm{J}$ Noncommun Dis 2016;1:3-8.

11. Dussa K, Parimalakrishnan S, Sahay R. Assessment of diabetes knowledge using diabetes knowledge questionnaire among people with Type 2 diabetes mellitus. Asian J Pharm Clin Res 2015;8(2):254-6.

12. Wang L, Waltenberger B, Pferschy-Wenzig EM, Blunder M, Liu X, Malainer $\mathrm{C}$, et al. Natural product agonists of peroxisome proliferatoractivated receptor gamma (PPAR $\gamma$ ): A review. Biochem Pharmacol 2014;92:73-89.

13. Grundy SM, Cleeman JI, Daniels SR, Donato KA, Eckel RH, Franklin BA, et al. Diagnosis and management of the metabolic syndrome: An American Heart Association/National Heart, Lung, and Blood Institute Scientific Statement. Circulation 2005;112(17):2735-52.

14. Fappa E, Yannakoulia M, Pitsavos C, Skoumas I, Valourdou S, Stefanadis C. Lifestyle intervention in the management of metabolic syndrome: Could we improve adherence issues? Nutrition 2008;24(3):286-91

15. Peter JS, Sabina EP. Global current trends in natural products for diabetes management: A review. Int J Pharm Pharm Sci 2016;8(4):20-8.

16. Grundy SM. Obesity, metabolic syndrome, and cardiovascular disease. J Clin Endocrinol Metab 2004;89(6):2595-600.

17. Mallappa RH, Rokana N, Duary RK, Panwar H, Batish VK, Grover S. Management of metabolic syndrome through probiotic and prebiotic interventions. Indian J Endocrinol Metab 2012;16(1):20-7.

18. Bairy PS, Das A, Nainwal LM, Mohanta TK, Kumawat MK, Mohapatra PK, et al. Design, synthesis and anti-diabetic activity of some novel xanthone derivatives targeting $\alpha$-glucosidase. Bangladesh J Pharmacol 2016;11:308-18.

19. Grygiel-Górniak B. Peroxisome proliferator-activated receptors and their ligands: Nutritional and clinical implications-a review. Nutr J 2014;13:17.

20. Miller BR, Nguyen H, Hu CJ, Lin C, Nguyen QT. New and emerging drugs and targets for Type 2 diabetes: Reviewing the evidence. Am Health Drug Benefits 2014;7(8):452-63.

21. Asche C, LaFleur J, Conner C. A review of diabetes treatment adherence and the association with clinical and economic outcomes. Clin Ther 2011;33(1):74-109.

22. Russo GL, Russo M, Ungaro P. AMP-activated protein kinase: A target for old drugs against diabetes and cancer. Biochem Pharmacol 2013;86(3):339-50.

23. Overton HA, Fyfe MC, Reynet C. GPR119, a novel G protein-coupled receptor target for the treatment of Type 2 diabetes and obesity. $\mathrm{Br} \mathrm{J}$ Pharmacol 2008;153 Suppl 1:S76-81.

24. Latruffe N, Vamecq J. Peroxisome proliferators and peroxisome proliferator activated receptors (PPARs) as regulators of lipid metabolism. Biochimie 1997;79(2-3):81-94.

25. Rosen ED, Hsu CH, Wang X, Sakai S, Freeman MW, Gonzalez FJ, et al. C/EBP alpha induces adipogenesis through PPAR gamma: A unified pathway. Genes Dev 2002;16(1):22-6.

26. Lewis SN, Garcia Z, Hontecillas R, Bassaganya-Riera J, Bevan DR. Pharmacophore modeling improves virtual screening for novel peroxisome proliferator-activated receptor-gamma ligands. J Comput Aided Mol Des 2015;29(5):421-39.

27. Stanley TB, Leesnitzer LM, Montana VG, Galardi CM, Lambert MH, Holt JA, et al. Subtype specific effects of peroxisome proliferatoractivated receptor ligands on corepressor affinity. Biochemistry 2003;42(31):9278-87.

28. de Groot JC, Weidner C, Krausze J, Kawamoto K, Schroeder FC, Sauer S, et al. Structural characterization of amorfrutins bound to the peroxisome proliferator-activated receptor $\gamma$. J Med Chem 2013;56(6):1535-43

29. Veeramachaneni GK, Raj KK, Bondili JS, Talluri VR. Screening and molecular docking studies of new natural agonists against peroxisome proliferator-activated receptor-alpha targeted to treat obesity. Asian J Pharm Clin Res 2016;9(4):80-4.

30. Semple RK, Chatterjee VK, O'Rahilly S. PPAR gamma and human metabolic disease. J Clin Invest 2006;116(3):581-9.

31. Auboeuf D, Rieusset J, Fajas L, Vallier P, Frering V, Riou JP, et al. Tissue distribution and quantification of the expression of mRNAs of peroxisome proliferator-activated receptors and liver $\mathrm{X}$ receptoralpha in humans: No alteration in adipose tissue of obese and NIDDM patients. Diabetes 1997;46(8):1319-27.

32. Fruchart JC. Peroxisome proliferator-activated receptor-alpha (PPARalpha): At the crossroads of obesity, diabetes and cardiovascular disease. Atherosclerosis 2009;205(1):1-8.
33. Barish GD, Narkar VA, Evans RM. PPAR delta: A dagger in the heart of the metabolic syndrome. J Clin Invest 2006;116(3):590-7.

34. Evans RM, Barish GD, Wang YX. PPARs and the complex journey to obesity. Nat Med 2004;10(4):355-61.

35. Luquet S, Gaudel C, Holst D, Jehl-Pietri C, Fredenrich A. Grimaldi PA. Roles of PPAR delta in lipid absorption and metabolism: A new target for the treatment of Type 2 diabetes. Biochim Biophys Acta 2005;1740(2):313-7.

36. Kaserer T, Obermoser V, Weninger A, Gust R, Schuster D. Evaluation of selected $3 \mathrm{D}$ virtual screening tools for the prospective identification of peroxisome proliferator-activated receptor (PPAR) $\gamma$ partial agonists. Eur J Med Chem 2016;124:49-62.

37. Tenenbaum A, Motro M, Fisman EZ. Dual and pan-peroxisome proliferator-activated receptors (PPAR) co-agonism: The bezafibrate lessons. Cardiovasc Diabetol 2005;4:14.

38. Berman HM, Battistuz T, Bhat TN, Bluhm WF, Bourne PE, Burkhardt $\mathrm{K}$, et al. The protein data bank. Acta Crystallogr D Biol Crystallogr 2002;58:899-907.

39. Chandra V, Huang P, Hamuro Y, Raghuram S, Wang Y, Burris TP, et al. Structure of the intact PPAR-gamma-RXR- nuclear receptor complex on DNA. Nature 2008;456(7220):350-6.

40. Zoete V, Grosdidier A, Michielin O. Peroxisome proliferator-activated receptor structures: Ligand specificity, molecular switch and interactions with regulators. Biochim Biophys Acta 2007;1771(8):915-25.

41. Salam NK, Huang TH, Kota BP, Kim MS, Li Y, Hibbs DE. Novel PPAR-gamma agonists identified from a natural product library: A virtual screening, induced-fit docking and biological assay study. Chem Biol Drug Des 2008;71(1):57-70.

42. Datar AP, Aher SB. Design and synthesis of novel thiazolidine-2,4diones as hypoglycemic agents. J Saudi Chem Soc 2016;20:196-201.

43. Begum A, Begum S, Prasad KV, Bharathi K. In silico studies on functionalized azaglycine derivatives containing 2, 4-thiazolidinedione scaffold on multiple targets. Int J Pharm Pharm Sci 2017;9(8):209-15.

44. Lehmann JM, Moore LB, Smith-Oliver TA, Wilkison WO, Willson TM, Kliewer SA. An antidiabetic thiazolidinedione is a high affinity ligand for peroxisome proliferator-activated receptor gamma (PPAR gamma). J Biol Chem 1995;270(22):12953-6.

45. Frias JP, Yu JG, Kruszynska YT, Olefsky JM. Metabolic effects of troglitazone therapy in Type 2 diabetic, obese, and lean normal subjects. Diabetes Care 2000;23(1):64-9.

46. Scheen AJ. Thiazolidinediones and liver toxicity. Diabetes Metab 2001;27(3):305-13.

47. Berlie HD, Kalus JS, Jaber LA. Thiazolidinediones and the risk of edema: A meta-analysis. Diabetes Res Clin Pract 2007;76(2):279-89.

48. Isley WL. Hepatotoxicity of thiazolidinediones. Expert Opin Drug Saf 2003;2(6):581-6

49. Villacorta L, Schopfer FJ, Zhang J, Freeman BA, Chen YE. PPAR- $\gamma$ and its ligands: Therapeutic implications in cardiovascular disease. Clin Sci (Lond) 2009;116(3):205-18.

50. Agrawal R, Jain P, Dikshit SN. Balaglitazone: A second generation peroxisome proliferator-activated receptor (PPAR) gamma $(\gamma)$ agonist. Mini Rev Med Chem 2012;12(2):87-97.

51. Guasch L, Sala E, Valls C, Blay M, Mulero M, Arola L, et al. Structural insights for the design of new PPARgamma partial agonists with high binding affinity and low transactivation activity. J Comput Aided Mol Des 2011;25(8):717-28.

52. Wojtowicz AK, Szychowski KA, Kajta M. PPAR- $\gamma$ agonist GW1929 but not antagonist GW9662 reduces TBBPA-induced neurotoxicity in primary neocortical cells. Neurotox Res 2014;25(3):311-22.

53. dos Santos JC, Bernardes A, Giampietro L, Ammazzalorso A, De Filippis B, Amoroso R, et al. Different binding and recognition modes of GL479, a dual agonist of peroxisome proliferator-activated receptor $\alpha / \gamma$. J Struct Biol 2015;191(3):332-40.

54. Gross B, Staels B. PPAR agonists: Multimodal drugs for the treatment of Type-2 diabetes. Best Pract Res Clin Endocrinol Metab 2007;21(4):687-710.

55. Zheng W, Qiu L, Wang R, Feng X, Han Y, Zhu Y, et al. Selective targeting of PPAR? By the natural product chelerythrine with a unique binding mode and improved antidiabetic potency. Sci Rep 2015;5:12222.

56. Sauer S. Amorfrutins: A promising class of natural products that are beneficial to health. Chembiochem 2014;15(9):1231-8.

57. Ye J. Challenges in drug discovery for thiazolidinedione substitute. Yao Xue Xue Bao 2011;1(3):137-42.

58. Grommes C, Landreth GE, Schlegel U, Heneka MT. The nonthiazolidinedione tyrosine-based peroxisome proliferator-activated receptor gamma ligand GW7845 induces apoptosis and limits migration and invasion of rat and human glioma cells. J Pharmacol Exp Ther 
2005;313(2):806-13.

59. Stienstra R, Duval C, Müller M, Kersten S. PPARs, obesity, and Inflammation. PPAR Res 2007;2007:95974.

60. Yoshimura R, Matsuyama M, Hase T, Tsuchida K, Kuratsukuri K, Kawahito $\mathrm{Y}$, et al. The effect of peroxisome proliferator-activated receptor-gamma ligand on urological cancer cells. Int J Mol Med 2003;12(6):861-5

61. Tyagi S, Gupta P, Saini AS, Kaushal C, Sharma S. The peroxisome proliferator-activated receptor: A family of nuclear receptors role in various diseases. J Adv Pharm Technol Res 2011;2(4):236-40.

62. Grommes C, Landreth GE, Heneka MT. Antineoplastic effects of peroxisome proliferator-activated receptor gamma agonists. Lancet Oncol 2004;5(7):419-29.
63. Sikka S, Chen L, Sethi G, Kumar AP. Targeting PPAR $\gamma$ Signaling cascade for the prevention and treatment of prostate cancer. PPAR Res 2012;2012:968040.

64. Boris M, Kaiser CC, Goldblatt A, Elice MW, Edelson SM, Adams JB, et al. Effect of pioglitazone treatment on behavioral symptoms in autistic children. J Neuroinflammation 2007;4:3.

65. Belfort R, Harrison SA, Brown K, Darland C, Finch J, Hardies J, et al. A placebo-controlled trial of pioglitazone in subjects with nonalcoholic steatohepatitis. N Engl J Med 2006;355(22):2297-307.

66. Shah DK, Menon KM, Cabrera LM, Vahratian A, Kavoussi SK, Lebovic DI. Thiazolidinediones decrease vascular endothelial growth factor (VEGF) production by human luteinized granulosa cells in vitro. Fertil Steril 2010;93(6):2042-7. 